\title{
Pengakuan Kembali Surakarta Sebagai Daerah Istimewa dalam Perspektif Historis dan Yuridis
}

\author{
Ni'matul Huda \\ Fakultas Hukum Universitas Islam Indonesia \\ Jl. Tamansiswa No. 158 Yogyakarta \\ penerbitan.fh@uii.ac.id
}

\begin{abstract}
This research is managed to answer three main problems: First, why was the Special Region of Surakarta obliterated? Second, is there any possibility to reconstruct and acknowledge the specialty of Surakarta? And, third, what attempts can be taken to make Surakarta acknowledged as Special Region again? This research aims at: First, understanding the background of the obliteration of Surakarta Special Region; second, studying the possibility of re-acknowledgement of the specialty of Surakarta, and third, finding out the attempts that can be conducted to acknowledge Surakarta as Special Region again. This research is a normative legal study using the regulations of law and several statutes as the primary legal material, and the literature relevant to the research object as the secondary legal material. This research uses the historical approach and statute approach. The analysis method used is qualitative descriptive. The conclusion of this research are: First, in historical perspective, the obliteration of Special District of Surakarta resulted from the social movement of the community called "gerakan anti swapraja" which demanded to revoke the special status of Surakarta. Second, the re-acknowledgement of the special status of Surakarta depends of the political will of Central Government, People Representative Council, Regional Government, Regional Legislative, and the community of Surakarta (ex Karesidenan Surakarta). Third, the attempt that can be conducted in order that Surakarta is re-acknowledged as a Special District is by the extension of the region or through the assessment of Law No. 10 of 1950 by Constitution Assembly.
\end{abstract}

Key words : Special region, asymmetric decentralization

\begin{abstract}
Abstrak
Penelitian ini mengangkat tiga masalah utama, pertama, mengapa Daerah Istimewa Surakarta dihapuskan? Kedua, dapatkah keistimewaan Surakarta diakui kembali? Ketiga, upaya apa yang dapat dilakukan untuk diakuinya kembali Surakarta sebagai Daerah Istimewa? Penelitian ini bertujuan , pertama, untuk mengetahui latar belakang mengapa Daerah Istimewa Surakarta dihapuskan. Kedua, untuk mengkaji kemungkinan keistimewaan Surakarta diakui kembali. Ketiga, upaya apa yang dapat dilakukan untuk diakuinya kembali Surakarta sebagai Daerah Istimewa. Penelitian ini adalah penelitian hukum normatif, yang menggunakan bahan hukum primer, berupa peraturan perundang-undangan dan berbagai maklumat. Sedangkan bahan hukum sekunder berupa literatur yang relevan dengan objek yang diteliti. Penelitian ini menggunakan pendekatan historis (historical approach) dan perundangundangan (statute approach). Metode analisis yang digunakan adalah deskriptif kualitatif. Penelitian ini menyimpulkan, pertama, dalam perspektif historis, dihapuskannya Daerah Istimewa Surakarta karena munculnya gejolak sosial di masyarakat berupa "gerakan anti swapraja", yang menuntut agar status keistimewaan Surakarta dicabut. Kedua, keistimewaan Surakarta dapat atau tidak diakui kembali sangat bergantung dari political will Pemerintah Pusat, DPR, Pemerintah Daerah, DPRD, dan masyarakat Surakarta (bekas Karesidenan Surakarta). Ketiga, upaya yang dapat dilakukan untuk diakuinya kembali Surakarta sebagai Daerah Istimewa, yaitu melalui pemekaran daerah atau melalui pengujian UU No. 10 Tahun 1950 ke Mahkamah Konstitusi.
\end{abstract}

Kata kunci: Daerah istimewa, desentralisasi asimetris. 


\section{Pendahuluan}

Di Surakarta, pada 18 Agustus 1945 Susuhunan Paku Buwono XII dan KGPAA Mangkunagoro VIII menyampaikan telegram dan ucapan selamat atas kemerdekaan Indonesia, diikuti Maklumat dukungan berdiri di belakang Republik Indonesia pada 1 September 1945. ${ }^{1}$ Dukungan Sunan Paku Buwono XII ini lebih awal dari dukungan dua kerajaan di Yogyakarta (Kasultanan dan Kadipaten) yang mengeluarkan Maklumatnya pada 5 September 1945.

Demikian pula yang terjadi di Yogyakarta, pada tanggal yang sama, Sri Sultan Hamengku Buwono IX dan Paku Alam VIII menyambutnya dengan gembira dan mengucapkan selamat kepada Soekarno dan Hatta sebagai Presiden dan Wakil Presiden Republik Indonesia ketika keduanya memproklamasikan kemerdekaan bangsa Indonesia. Dua hari kemudian Sultan dan Paku Alam mengirim telegram ke Jakarta bahwa dirinya siap berdiri di belakang Soekarno-Hatta. ${ }^{2}$

Soekarno sebagai Presiden Republik Indonesia menyambut hangat tindakan Paku Buwono, Mangkunagoro, Sultan Hamengku Buwono, dan Paku Alam. Bahkan satu hari sesudah Paku Buwono, Mangkunagoro, Sultan Hamengku Buwono dan Paku Alam mengirim ucapan selamat, Presiden sudah mengeluarkan Piagam Kedudukan yang menetapkan Susuhunan Paku Buwono XII, KGPAA Mangkunagoro VIII, Sri Sultan Hamengku Buwono IX dan Sri Paku Alam VIII pada kedudukannya masing-masing. Dengan piagam termaksud kepada beliau-beliau itu ditaruhkan segala pikiran, tenaga, jiwa, dan raga untuk keselamatan daerahnya sebagai bagian dari Republik Indonesia. ${ }^{3}$

Berhubung dengan kesibukannya yang luar biasa, Pemerintah Republik Indonesia belum sempat mengatur kedudukan Kasunanan Surakarta, Mangkunegaran, Kasultanan Yogyakarta dan Pakualaman sebagai daerah istimewa yang dimaksud dalam UUD 1945. Hal-hal yang seharusnya diatur Pusat itu bahkan kemudian diatur sendiri oleh Susuhunan Paku Buwono XII, KGPAA Mangkunagoro VIII, Sri Sultan HB IX dan Sri Paku Alam VIII. Melalui Maklumatnya Sunan Paku Buwono XII dan

${ }^{1}$ Lihat Imam Samroni dkk. (Penulis), Daerah Istimewa SURAKARTA, Wacana Pembentukan Provinsi Daerah Istimewa Surakarta Ditinjau dari Perspektif Historis, Sosiologis, Filosofis, \& Yuridis, Pura Pustaka, Yogyakarta, 2010, hlm. 295-296.

${ }^{2}$ Kustiniyah Mochtar, "Pak Sultan dari Masa ke Masa", dalam Atmakusumah (Penyunting), Tabta untuk Rakyat, Gramedia, Jakarta, 1982, hlm. 64-65.

${ }^{3}$ Ni'matul Huda, DIY dalam Perdebatan Konstitusi dan Peraturan Perundang-undangan di Indonesia, Nusa Media, Bandung, 2013, hlm. 140. 
KGPAA Mangkunagoro VIII telah menyatakan Surakarta Hadiningrat yang bersifat kerajaan adalah daerah istimewa dari Negara Republik Indonesia.

Dari amanat-amanat yang dikeluarkan oleh Susuhunan Paku Buwono XII, KGPAA Mangkunagoro VIII, Sri Sultan HB IX dan Sri Paku Alam VIII tersebut, dapat disimpulkan bahwa, pertama, baik Kasunanan Surakarta, Mangkunegaran, Kasultanan Yogyakarta maupun Kadipaten Paku Alaman, masing-masing merupakan Daerah Istimewa dari Negara Republik Indonesia, jadi belum merupakan satu kesatuan Daerah Istimewa. Kedua, dengan adanya pernyataan (Maklumat/Amanat) tersebut memperjelas posisi kerajaan-kerajaan tersebut adalah memihak kepada Republik Indonesia yang baru lahir. Ketiga, baik Sunan, Sultan maupun Paku Alam masing-masing sebagai pemegang kekuasaan dalam Kasunanan, Kasultanan dan Kadipaten berhubungan langsung dengan dan hanya bertanggungjawab kepada Presiden RI. ${ }^{4}$

Sehari setelah dikeluarkannya Maklumat Paku Buwono XII, Amanat dari Sri Sultan HB IX dan Amanat dari Sri Paku Alam VIII, pada tanggal 6 September 1945, baik Sri Susuhunan Paku Buwono XII, KGPAA Mangkunagoro VIII, Sri Sultan Hamengku Buwono IX maupun Sri Paku Alam VIII, menerima Piagam Kedudukan dari Presiden Republik Indonesia tertanggal 19 Agustus 1945, yang disampaikan oleh dua orang Menteri Negara ialah Mr. Sartono dan Mr. Maramis. ${ }^{5}$

Setelah kemerdekaan Republik Indonesia, Kasultanan Yogyakarta dan Pakualaman memperoleh status Daerah Istimewa, yang kemudian menjadi Daerah Istimewa Yogyakarta (DIY). Tidak demikian halnya dengan Kasunanan Surakarta dan Mangkunegaran. Status daerah Surakarta tidak dikukuhkan seperti DIY menjadi Daerah Istimewa Surakarta, tetapi justru dihapuskan, dan Surakarta digabungkan ke dalam Provinsi Jawa Tengah. ${ }^{6}$

Di Surakarta belakangan muncul gejolak yang menuntut dikembalikannya keistimewaan Surakarta. Sebagian masyarakat memahami Penetapan Presiden No. 16/ SD Tahun 1946 tersebut hanya untuk sementara waktu dan tidak ada maksud dan tujuan Pemerintah Pusat untuk menghapuskan daerah Surakarta yang bersifat istimewa.7 Akan

\footnotetext{
${ }^{4}$ Ibid., hlm. 142-143.

${ }^{5}$ Soedarisman Poerwokoesoemo, Daerah Istimewa Yogyakarta, Gadjahmada University Press, Yogyakarta, 1984, hlm. 251-252.

${ }^{6}$ Lihat Undang-Undang Nomor 10 Tahun 1950 tentang Pembentukan Propinsi Djawa Tengah Bagian Memutuskan angka I dan Pasal 1 ayat (1).

${ }^{7}$ Imam Samroni dkk (Penulis), Daerah Istimewa SURAKARTA, Wacana Pembentukan Provinsi Daerah Istimewa Surakarta Ditinjau dari Perspektif Historis, Sosiologis, Filosofis, \& Yuridis, Pura Pustaka, Yogyakarta, 2010.
} 
tetapi, hingga saat ini tuntutan status keistimewaan bagi Surakarta tidak ada tindak lanjutnya dari Pemerintah. Adanya perbedaan perkembangan status dua daerah istimewa - di DIY dan Provinsi Jawa Tengah - tersebut menarik untuk diteliti, baik dari perpsektif historis maupun yuridis.

\section{Rumusan Masalah}

Penelitian ini mengangkat tiga masalah utama, pertama, mengapa Daerah Istimewa Surakarta dihapuskan? Kedua, dapatkah keistimewaan Surakarta diakui kembali? Ketiga, upaya apa yang dapat dilakukan untuk diakuinya kembali Surakarta sebagai Daerah Istimewa?

\section{Tujuan Penelitian}

Penelitian ini bertujuan, pertama, untuk mengetahui latar belakang mengapa Daerah Istimewa Surakarta dihapuskan. Kedua, untuk mengkaji kemungkinan keistimewaan Surakarta diakui kembali. Ketiga, upaya apa yang dapat dilakukan untuk diakuinya kembali Surakarta sebagai Daerah Istimewa.

\section{Metode Penelitian}

Penelitian ini adalah penelitian hukum normatif, yaitu penelitian yang dilakukan dengan cara meneliti bahan pustaka (library research). Adapun objek penelitiannya adalah pengakuan kembali surakarta sebagai daerah istimewa dalam perspektif yuridis.

Bahan hukum yang digunakan dalam penelitian ini adalah bahan hukum primer yang berupa peraturan perundang-undangan dan berbagai maklumat. Sedangkan bahan hukum sekunder berupa literatur yang relevan dengan objek yang diteliti.

Dalam penelitian ini pengumpulan bahan hukum dilakukan dengan cara studi dokumen, yaitu mengkaji, menelaah, dan mempelajari bahan-bahan hukum yang ada kaitannya dengan penelitian ini. Penelitian ini menggunakan pendekatan historis (historical approach) dan perundang-undangan (statute approach). ${ }^{8}$ Metode analisis bahan hukum yang digunakan dalam penelitian ini adalah deskriptif kualitatif.

${ }^{8}$ Johnny Ibrahim, Teori \& Metodologi Penelitian Hukum Normatif, Cet. Kedua, Bayumedia, Malang, 2006, hlm. 302-303 dan 318. 


\section{Hasil Penelitian dan Pembahasan}

\section{Desentralisasi Asimetris di Indonesia}

Secara umum pengadopsian model desentralisasi asimetris didasari kebutuhan akan kerangka administrasi yang handal dalam mengelola keragaman lokal. Format pengorganisasian negara dilihat sebagai wujud respon atas realitas keberagaman masyarakat sebagai sumber input bagi bekerjanya sistem politik/pemerintahan. Ahli pertama yang memulai debat seputar desentralisasi asimetris adalah Charles Tarlton dari University of California, USA. Menurut Tarlton: ${ }^{9}$

"Pembeda inti antara desentralisasi biasa (simetris) dan desentralisasi asimetris terletak pada tingkat kesesuaian (conformity), dan keumuman (commonality) pada hubungan suatu level pemerintahan (negara bagian/daerah) dengan sistem politik, dengan pemerintah pusat maupun antar negara bagian/daerah. Pola simetris ditandai oleh "the level of conformity and commonality in the relations of each separate political unit of the system to both the system as a whole and to the component units". Di sini, hubungan simetris antar setiap unit lokal dengan pemerintah pusat tersebut didasari jumlah dan bobot kewenangan yang sama".

Sementara dalam pola asimetris, satu atau lebih unit politik atau pemerintahan lokal "possessed of varying degrees of autonomy and power". Berbedanya derajat otonomi kekuasaan berupa ketidakseragaman pengaturan muatan kewenangan itu membentuk derajat hubungan yang berbeda pula antar negara bagian/daerah asimetris dengan unit-unit politik lainnya, baik secara horisontal (antar daerah) maupun vertikal (dengan pusat). Khusus mengenai pola asimetris, Tarlton menekankan, "In the model asymmetrical system each component unit would have about it a unique feature or set of features which would separate in important ways, its interest from those of any other state or the system considered as a whole". ${ }^{10}$

Kerangka pikir Tarlton di atas diadopsi sekaligus diperbarui oleh John McGarry dari Queen's University, Canada. Titik tekannya tidak hanya terkait substansi asimetri tetapi juga bentuk dasar legal pengaturannya. Menurut McGarry:11

"Model asimetris terjadi kalau otonomi semua unit pemerintahan subnasional dijamin konstitusi dan terdapat sekurangnya satu unit lokal yang menikmati level otonomi yang berbeda (umumnya otonomi lebih luas). Di negara federal,

\footnotetext{
${ }^{9}$ Robert Endi Jaweng, "Kritik terhadap Desentralisasi Asimetris di Indonesia”, Jurnal Analisis CSIS, Vol. 40, No. 2, Juni 2011, hlm. 162.

10 Ibid.

${ }^{11}$ Ibid., hlm. 163.
} 
sekaligus sebagai kebalikan dari negara unitaris, keberadaan model asimetris diatur dalam konstitusi dan otoritas federal tidak bisa secara sepihak menarik atau membatalkan status asimetris tersebut. Dalam perspektif politik, asimetris yang diatur dalam konstitusi ini adalah bukti pengakuan negara akan keberagaman sifat nasional satu atau lebih wilayah".

Walaupun pada awalnya Tarlton menulis tema asimetris dalam kerangka negara federal, tetapi dalam perkembangan di kemudian hari menunjukkan bahwa konsep dan penerapan kebijakan atas model tersebut mulai diadopsi di negara kesatuan, misalnya di Indonesia berupa otonomi khusus, daerah khusus, dan daerah istimewa.

Di dalam Bab VI UUD 1945 (sebelum amandemen) tentang Pemerintahan Daerah, sudah ditentukan pengaturan daerah di Indonesia secara asimetris. Hal itu terlihat dalam rumusan Pasal 18: "Pembagian daerah Indonesia atas daerah besar dan kecil, dengan bentuk susunan pemerintahannya ditetapkan dengan undangundang, dengan memandang dan mengingati dasar permusyawaratan dalam sistem pemerintahan negara, dan hak-hak asal-usul dalam daerah-daerah yang bersifat istimewa." Kemudian dalam Penjelasan Pasal 18 UUD 1945 ditegaskan:

“...Dalam teritoir Negara Indonesia terdapat lebih kurang 250 zelfbesturende landchappen dan volksgemeenschappen, seperti desa di Jawa dan Bali, negeri di Minangkabau, dusun dan marga di Palembang dan sebagainya. Daerah-daerah itu mempunyai susunan asli, dan oleh karenanya dapat dianggap sebagai daerah yang bersifat istimewa. Negara Republik Indonesia menghormati kedudukan daerah-daerah istimewa tersebut dan segala peraturan negara yang mengenai daerah-daerah itu akan mengingati hak asal-usul daerah tersebut."

Siapakah yang dimaksud dengan daerah- daerah yang bersifat istimewa dalam Pasal 18 UUD 1945 tersebut? Menurut The Liang Gie, “ ...yang nyata-nyata dianggap daerah istimewa dengan hak-hak asal-usul ialah zelfbesturende landschappen, yaitu daerah-daerah kerajaan/kesultanan yang masih ada di seluruh Indonesia pada waktu itu." 12

Setelah UUD 1945 diamandemen, pengaturan tentang daerah istimewa dan daerah (otonomi) khusus juga diakomodir dalam Pasal 18B ayat (1), yang berbunyi: "Negara mengakui dan menghormati satuan-satuan pemerintahan daerah yang bersifat khusus atau bersifat istimewa yang diatur dengan undang-undang". Di tingkat peraturan perundang-undangan, desentralisasi asimetris terlihat

${ }^{12}$ The Liang Gie, Kumpulan Pembahasan terhadap Undang-Undang Tentang Pokok-pokok Pemerintahan Daerah Indonesia, Edisi Kedua, Cetakan Kedua, Supersukses, Yogyakarta, 1982, hlm. 10. 
pengaturannya untuk pertama kalinya dalam UU No. 1 Tahun 1945 tentang Peraturan Mengenai Kedudukan Komite Nasional Indonesia Daerah, yang mengecualikan daerah Surakarta dan Yogyakarta dalam pembentukan Komite Nasional Daerah.

Paradigma uniformitas menafikan fakta keragaman yang melekat dalam daerah-daerah dan sekaligus menafikan kepentingan nasional dalam kerangka desentralisasi, seperti kepentingan untuk menjaga keutuhan negara. Yang tampak kemudian, ide penyebaran kekuasaan lewat desentralisasi dilaksanakan secara seragam untuk semua daerah tanpa mempertimbangkan perbedaan-perbedaan fundamental antar berbagai daerah, dan tanpa mempertimbangkan keunikan atau kekhususan yang dimiliki daerah-daerah, dan tanpa mempertimbangkan kepentingan nasional di masing-masing daerah. ${ }^{13}$

Paradigma yang semacam ini dikenal sebagai asymmetrical decentralization yang secara legal konstitusional sebenarnya memiliki akar yang kuat pada konstitusi dan spirit yang inherent dalam praktek desentralisasi Indonesia sejak awal kemerdekaan, tetapi tidak dirumuskan secara tajam dalam regulasi-regulasi nasional mengenai desentralisasi. Bahkan penafsiran atas UU No. 5 Tahun 1974 tentang Pokok-pokok Pemerintahan di Daerah yang sentralistis sekalipun mengindikasikan adanya ruang bagi bekerjanya desentralisasi asimetris, sekalipun gagal diwujudkan. ${ }^{14}$

Meski dalam realitasnya Indonesia menerapkan model tersebut dan dari sisi konstitusi juga memang diatur keberadaannya dalam bentuk pengakuan atas satuansatuan pemerintahan daerah yang bersifat khusus/istimewa, hingga kini Pemerintah belum memiliki desain kebijakan yang jelas guna menata dan mengelola keragaman lokalitas ke dalam kerangka desentralisasi asimetris. Lebih lanjut, Pemerintah juga masih gagal dalam mengkapitalisasi penerapan desentralisasi asimetris ke dalam tujuan-tujuan strategis nasional maupun untuk kepentingan daerah bersangkutan. ${ }^{15}$

Setelah jatuhnya pemerintahan Orde Baru, di sejumlah daerah telah muncul berbagai tuntutan, ada yang ingin memisahkan diri dari Indonesia dengan meminta referendum, menawarkan perubahan bentuk negara federal, ada pula keinginan

\footnotetext{
${ }^{13}$ Cornelis Lay, "Desentralisasi Asimetris Bagi Indonesia”, makalah yang dipresentasikan dalam Seminar Nasional “Menata Ulang Desentralisasi dari Perspektif Daerah”, yang diselenggarakan oleh Program Pascasarjana Program Studi Ilmu Politik Fisipol UGM kerjasama dengan USAID dan DRSP, Yogyakarta, 25 Januari 2010, hlm. 1-2.

${ }^{14}$ Ibid.

${ }^{15}$ Robert Endi Jaweng, "Kritik terhadap Desentralisasi Asimetris di Indonesia”, Analisis CSIS, Vol. 40, No. 2,Juni 2011, hlm. 161.
} 
yang kuat untuk mendapatkan status "istimewa" atau "khusus" sebagaimana yang diamanatkan dalam UUD 1945 Pasal 18B.

Secara empirik Indonesia telah melaksanakan desentralisasi asimetris di Nanggrou Aceh Darussalam (NAD), Papua, Daerah Istimewa Yogyakarta (DIY) dan Daerah Khusus Ibukota (DKI) Jakarta. Status daerah istimewa dan otonomi khusus yang diberikan kepada Provinsi Aceh, dengan sejumlah urusan yang diistimewakan dan dikhususkan, dimaksudkan untuk mengurangi potensi konflik yang tidak berkesudahan. Undang-Undang Nomor 44 Tahun 1999 memberikan pengakuan keistimewaan Daerah Istimewa Aceh didasarkan pada sejarah, yaitu karakter khas sejarah perjuangan masyarakat Aceh yang memiliki ketahanan dan daya juang tinggi. Ketahanan dan daya juang tinggi tersebut bersumber dari pandangan hidup yang berlandaskan syari'at Islam yang melahirkan budaya Islam yang kuat, sehingga Aceh menjadi salah satu daerah modal bagi perjuangan dalam merebut dan mempertahankan kemerdekaan Negara Kesatuan Republik Indonesia. ${ }^{16}$

Sedangkan pengakuan keistimewaan Daerah Istimewa Yogyakarta ${ }^{17}$ didasarkan pada aspek kesejarahan yaitu Kasultanan Ngayogyakarta Hadiningrat dan Kadipaten Pakualaman yang telah mempunyai wilayah, pemerintahan, dan penduduk sebelum lahirnya Negara Kesatuan Republik Indonesia pada tanggal 17 Agustus 1945 berperan dan memberikan sumbangsih yang besar dalam mempertahankan, mengisi, dan menjaga keutuhan Negara Kesatuan Republik Indonesia.

Sejarah Indonesia mencatat, bahwa penyelenggaraan pemerintahan daerah dengan formula otonomi khusus pernah ditawarkan di Provinsi Timor Timur, namun gagal dilaksanakan karena masyarakat Timor Timur lebih memilih merdeka (melepaskan diri dari Indonesia), dan akhirnya Timor Timur lepas dari NKRI. Belakangan muncul kembali formula otonomi khusus yang ditawarkan kepada masyarakat Aceh dan Papua. Di Aceh otonomi khusus yang diberikan melalui UU No. 18 Tahun 2001 hanya bertahan \pm 5 (lima) tahun, dan akhirnya juga ditolak oleh masyarakat Aceh melalui perjanjian di Helsinki. Begitu pula yang terjadi di Papua,

${ }^{16}$ Lihat UU No. 22 Tahun 1999 tentang Pemerintahan Daerah Penjelasan Pasal 122, "Pengakuan keistimewaan Propinsi Istimewa Aceh didasarkan pada sejarah perjuangan kemerdekaan nasional, sedangkan isi keistimewaannya berupa pelaksanaan kehidupan beragama, adat, dan pendidikan serta memperhatikan peranan ulama dalam penetapan kebijakan Daerah".

${ }^{17}$ Lihat UU No. 22 Tahun 1999 tentang Pemerintahan Daerah Pasal 122 menegaskan bahwa: “Keistimewaan untuk Propinsi Daerah Istimewa Aceh dan Propinsi Daerah Istimewa Yogyakarta, sebagaimana dimaksud dalam UU No. 5 Tahun 1974, adalah tetap dengan ketentuan bahwa penyelenggaraan pemerintahan Propinsi Istimewa Aceh dan Propinsi Istimewa Yogyakarta didasarkan pada undang-undang ini”. 
otonomi khusus juga banyak menimbulkan masalah karena pada awalnya yang diakui mendapatkan 'berkah' dari otonomi khusus hanyalah Provinsi Papua sebagai peleburan dari Provinsi Irian Jaya, padahal sebelumnya sudah lahir Propinsi Papua Barat dan lain-lain.

\section{Mengapa Daerah Istimewa Surakarta Dihapuskan?}

Sebagaimana sudah diuraikan di atas, untuk pertama kalinya pengaturan tentang Daerah Istimewa muncul dalam UU No. 1 Tahun 1945, yang dalam penjelasan Pasal 1-nya menyatakan: "Komite Nasional Daerah diadakan di Jawa dan Madura (kecuali di Daerah Istimewa Yogyakarta dan Surakarta) di Karesidenan di kota berautonomi, Kabupaten dan lain-lain daerah yang dipandang perlu oleh Menteri Dalam Negeri...". Pengecualian terhadap Surakarta dan Yogyakarta ini bisa dimaklumi karena keduanya merupakan wilayah kerajaan yang baru saja bergabung dengan republik. Karena itu, struktur pemerintahan lokalnya diberi peluang menggunakan aturan yang berlainan.

Daerah Surakarta dan Yogyakarta pada zaman penjajahan Belanda masingmasing adalah Daerah Swapraja yang besar pengaruhnya. Pada awal revolusi 1945, kedua daerah swapraja tersebut menunjukkan perkembangan yang sangat berbeda, sehingga sikap pemerintah terhadap kedua daerah (swapraja) tersebut pada mulanya belum tegas benar. Namun demikian, tidak dapat diragukan lagi bahwa UU No. 1 Tahun 1945 tidak memandang kedua daerah tersebut seperti daerah karesidenan biasa. Jadi ada keistimewaannya. Keistimewaan yang hanya terlihat secara samar-samar (implisit) dalam Pasal 1 UU No. 1 Tahun 1945 tersebut dinyatakan secara tegas (eksplisit) dalam penjelasan pasal yang bersangkutan, yakni yang antara lain berbunyi sebagai berikut. ${ }^{18}$

"Pasal Pertama: Komite Nasional Daerah diadakan di Jawa dan Madura (kecuali di Daerah Istimewa Jogyakarta dan Surakarta) di karesidenan, di kota berotonomi, kabupaten dan lain-lain daerah yang dipandang perlu oleh Menteri Dalam Negeri. a. Ini berarti bahwa Komite Nasional Daerah di Propinsi, Kawedanan, Asistenan (Kecamatan) dan Si-ku dan Ku dalam kota, tak perlu dilanjutkan lagi.

b. Tentang Jogyakarta dan Surakarta,dalam surat pengantar rancangan undangundang tersebut diterangkan bahwa ketika merundingkan rancangan itu, Badan Pekerja Pusat tidak mempunyai gambaran yang jelas. Jika begitulah surat pengantar sekiranya Pemerintah menganggap perlu untuk daerah tersebut diadakan aturan yang berlainan, Badan Pekerja bersedia menerima untuk membicarakannya- rancangan undang-undang yang mengenai daerah itu."

\footnotetext{
${ }^{18}$ Rochmat Soemitro, Peraturan Perundang-undangan tentang Pemerintahan Daerab dari Tahun 1945 s/d 1983 dengan
} Komentar, Eresco-Tarate, Jakarta - Bandung, 1983, hlm. 43. 
Dari ketentuan Pasal 1 UU No. 1 Tahun 1945 beserta Penjelasannya dapat diketahui bagaimana suasana kejiwaan dan arah pemikiran di kalangan pemimpinpemimpin Indonesia ketika itu tentang Daerah-daerah Swapraja Yogyakarta dan Surakarta. Tidak dibentuknya Komite Nasional Daerah di Daerah Istimewa Yogyakarta dan Surakarta itu bukan karena BP KNIP tidak menyetujui diberikannya otonomi kepada Daerah Istimewa, tetapi karena Badan Pekerja Pusat tidak mempunyai gambaran yang jelas mengenai daerah itu. Sekiranya Pemerintah menganggap perlu adanya undang-undang yang khusus mengatur Daerah Istimewa itu, maka Badan Pekerja Pusat bersedia membicarakannya. ${ }^{19}$

Setelah kemerdekaan Republik Indonesia, Kasultanan Yogyakarta dan Pakualaman memperoleh status Daerah Istimewa, yang kemudian menjadi Daerah Istimewa Yogyakarta. Tidak demikian dengan Kasunanan Surakarta dan Mangkunegaran. Hal demikian karena adanya "Gerakan Anti Swapradja" 20 pada masa revolusi kemerdekaan yang dimotori oleh kelompok intelektual, pemuda dan pelajar di bawah pimpinan kerabat keraton sendiri yaitu KPH Mr. Sumodiningrat. ${ }^{21}$

Di samping itu, Kasunanan Surakarta dan Mangkunegaran tidak bisa bekerjasama seperti Kasultanan dan Kadipaten di Yogyakarta (Amanat 30 Oktober 1945). Kemungkinan hal itu disebabkan karena yang satu tidak mau berada di bawah yang lainnya atau sebaliknya, sebab kedua-duanya merasa dirinya sama-sama tinggi dan kuatnya. Dari pihak Sri Mangkunegara tidak pernah ada kesediaan untuk menerima fungsi hanya sebagai Wakil Kepala Daerah Istimewa Surakarta. Tidak pernah ada tanda-tanda yang menunjukkan kesediaan Sri Mangkunegara untuk memegang fungsi di bawah Sri Sunan. Tuntutan beliau adalah agar Kasunanan Surakarta dijadikan daerah istimewa sendiri di bawah Sri Sunan, sedangkan Mangkunegaran harus dijadikan daerah istimewa juga di bawah pimpinan Sri Mangkunegara, yang berdiri sendiri sebagai daerah istimewa Mangkunegaran di samping, bukan di bawah Daerah Istimewa Kasunanan. Jadi di Surakarta tidak pernah

\footnotetext{
${ }^{19}$ Sujamto, Daerah Istimewa dalam Negara Kesatuan RI, Bina Aksara, Jakarta, 1988, hlm. 25.

${ }^{20}$ Gerakan anti swapraja ini kemudian berkembang menjadi aksi penculikan terhadap pembesar-pembesar istana dan aksi melepaskan diri di berbagai daerah yang dulunya menjadi wilayah tradisional Surakarta. Fase sejarah gerakan anti swapraja ini seringkali disebut "Revolusi Sosial” di Surakarta. Lihat dalam AA. GN. Ari Dwipayana, "Aristokrasi di Dua Kota", dalam Jamil Gunawan dkk. (Editor), Desentralisasi, Globalisasi, dan Demokrasi Lokal, LP3ES, Jakarta, 2005, hlm. 148.

${ }^{21}$ Edy S. Wirabumi, Pemberdayaan Hukum Otonomi Daerah dan Potensi Wilayah: Studi tentang Kemungkinan Terbentuknya Provinsi Surakarta, Disertasi, Program Doktor Ilmu Hukum, Pascasarjana Universitas Diponegoro, Semarang, 2007, hlm. 138-139.
} 
tercapai kata sepakat untuk mendirikan hanya satu Daerah Istimewa sebagai gabungan daripada Kasunanan Surakarta dan Daerah Mangkunegaran sebagaimana halnya di Yogyakarta. ${ }^{22}$

Pada September 1945 KND mulai dibentuk di Surakarta. Raden Pandji Suroso menjadi Komisaris Tinggi Pemerintah RI yang berkedudukan di Kota Surakarta. Atas usul Badan Pekerja KND, Komisaris Tinggi menyetujui dibentuknya Pemerintahan Direktorium untuk daerah Surakarta. Pemerintahan ini diketuai oleh Komisaris Tinggi dan mempunyai 9 anggota, yaitu 5 dari KND dan 4 merupakan wakil-wakil yang ditunjuk oleh Sri Paku Buwono dan Mangkunagoro. ${ }^{23}$

Sejak pembentukan Komisaris Tinggi yang berkuasa di seluruh daerah Surakarta (Kasunanan dan Mangkunegaran) pada hakikatnya sudah bukan lagi Sri Sunan dan Sri Mangkunegoro atau Pepatih Dalemnya masing-masing, melainkan sejak saat itu yang memegang kekuasaan tidak lain adalah Komisaris Tinggi RI bersama-sama Komite Nasional Indonesia sebagai wakil rakyat dan sehari-hari Direktorium tersebut. Semua kabupaten dalam kedua daerah tersebut pada akhirnya satu persatu memisahkan diri dari Kasunanan Surakarta dan daerah Mangkunegaran dan menggabungkan diri ke dalam Republik Indonesia langsung di bawah pimpinan Komisaris Tinggi sebagai wakil Republik Indonesia yang sah. ${ }^{24}$

Berlainan dengan perubahan-perubahan di Yogyakarta yang berlangsung dengan tenang, di Surakarta terjadi pergolakan-pergolakan. Pemerintahan Direktorium tidak dapat berjalan lancar, karena pihak Mangkunegaran kurang menyetujui bentuk ini. Di dalam masyarakat mulai timbul gerakan-gerakan yang anti kedua landschappen itu. Di lingkungan para pegawai sendiri juga timbul ketidakpuasan terhadap pembesar-pembesar keraton dan mulai menuntut agar pejabat-pejabat itu diganti dengan tenaga-tenaga yang berjiwa revolusioner. ${ }^{25}$

\footnotetext{
${ }^{22}$ Soedarisman Poerwokoesoemo, Daerah Istimewa..., Op. Cit., hlm. 21-22. Lihat juga dalam Selo Soemardjan, Perubahan Sosial di Yogyakarta, Cet.Ketiga, Gadjah Mada University Press, Yogyakarta, 1991, hlm. 94-95.

${ }^{23}$ The Liang Gie, Pertumbuban Pemerintahan Daerah di Negara Republik Indonesia, Liberty, Yogyakarta, 1993, hlm. 79. Lihat juga Edy S. Wirabumi, Loc. Cit. Berbeda dengan di Yogyakarta yang tidak membentuk Komisaris Tinggi, yang sebenarnya diperuntukkan bagi “empat daerah Kerajaan Jawa” yang disebut "Praja Kejawen”, yakni Kasunanan Surakarta, Mangkunegaran, Kasultanan dan Paku Alaman, sampai jabatan Komisaris Tinggi untuk Daerah Istimewa Surakarta dan Yogyakarta dihapuskan oleh Penetapan Presiden Tahun 1946 No. 16/SD. Pembentukan Komisaris Tinggi di Yogyakarta ditolak oleh Sri Sultan karena Sri Sultan dalam Amanat 5 September 1945 sudah menegaskan bahwa segala kekuasaan di daerahnya berada di tangannya seluruhnya dan bahwa perhubungan antara Kasultanan Yogyakarta dengan Republik Indonesia bersifat langsung dan Sri Sultan bertanggungjawab langsung kepada Presiden RI. Penegasan tersebut lebih dikuatkan lagi dalam Amanat 30 Oktober 1945 diktum keempat yang menyatakan bahwa: "Paduka Tuan Komisaris Tinggi pada tanggal 22-10-1945 di Kepatihan Yogyakarta di hadapan Kami berdua dengan disaksikan oleh para Pembesar dan para Pemimpin telah menyatakan tidak perlunya akan adanya Subcomissariat dalam daerah kami berdua." Baca Soedarisman Poerwokoesoemo, Daerah Istimewa..., Op. Cit., hlm. 25-26 dan 256-257.

${ }^{24}$ Soedarisman Poerwokoesoemo, Daerah Istimewa. ..,Ibid.

${ }^{25}$ Sunan Paku Buwono XII yang baru menggantikan ayahnya pada tahun 1944 tidak memikirkan pemerintahan,
} 
KNID yang dipimpin Mr. Sumodiningrat, ipar Sunan tidak efektif. Pada 29 Oktober Ir. Sakirman, saudara S. Parman datang ke Surakarta dan mengubah organisasi KNID Surakarta sesuai dengan Maklumat No. X. Pada 1 November dibentuk BPKNID dengan ketuanya seorang veteran PKI sebelum perang, dan dikuasai oleh berbagai golongan pemuda yang berpendirian radikal dan tokohtokoh dari pergerakan. Komisaris Tinggi pun tidak dapat mengakomodasikan gerakan rakyat itu dalam suatu Direktorium yang dibentuknya. Hal ini antara lain disebabkan karena pemerintahan keraton dikuasai orang-orang yang masih mengharapkan kembalinya Belanda dan tidak ada kerja sama antara Kasunanan dan Mangkunegaran. ${ }^{26}$

Ketika itu dalam masyarakat tengah berkembang sikap anti swapraja, termasuk gerakan protes terhadap pembentukan Daerah Istimewa Surakarta yang direncanakan oleh Menteri Dalam Negeri dr. Sudarsono. Gerakan protes yang dimotori oleh kaum intelektual, pemuda dan pelajar menganggap bahwa terbentuknya Daerah Istimewa Surakarta akan membangkitkan kembali sistem feodalisme yang bertentangan dengan nilai-nilai demokratis di alam kemerdekaan. Ketika itu timbul pula peristiwa penculikan beberapa pembesar Kantor Kepatihan Karaton Surakarta. ${ }^{27}$

Rencana Menteri Dalam Negeri untuk membentuk Daerah Istimewa Surakarta itu batal dilaksanakan dan mulai 1 Juni 1946 Surakarta di bawah Pemerintahan Rakyat dan Tentara Daerah Surakarta, yang beranggotakan wakil-wakil dari partai politik dan sejumlah intelektual. Kasunanan dan Mangkunegaran kehilangan kekuasaan politiknya setelah dikeluarkannya Peraturan Pemerintah No. 16/SD Tahun 1946 tanggal 15 Juli 1946, ${ }^{28}$ karena daerah Surakarta menjadi Karesidenan,

sehingga pemerintahan tetap di bawah kekuasaan Pepatih Dalem beserta kelompoknya yang masih mengharapkan kedatangan Belanda. Hal ini menimbulkan kerenggangan antara kelompok pergerakan dengan Keraton, yang sangat merugikan kedudukan keraton dalam masa revolusi itu. Lihat P.J. Suwarno, Hamengku Bunono IX dan Sistem Birokrasi Pemerintahan Yogyakarta 1942-1974: Sebuah Tinjanan Historis, Kanisius, Yogyakarta, 1994, hlm. 173. Lihat juga AA. GN. Ari Dwipayana, "Aristokrasi di Dua Kota”..., Op. Cit, hlm. 149.

${ }^{26}$ Anderson, Revolusi Pemoeda Pendudukan Jepang dan Perlawanan di Jawa 1944-1946, Pustaka Sinar Harapan, Jakarta, 1988, hlm. 385-387. Dikutip kembali oleh P.J. Suwarno, Hamengku...,Ibid., hlm.188. Lihat juga Wirabumi, Pemberdayaan ..., Op.Cit., hlm. 139.

${ }^{27}$ Wirabumi, Ibid.

${ }^{28}$ Di dalam PP No. 16/SD Tahun 1946 disebutkan bahwa: "Sebelum bentuk susunan Pemerintah Daerah Kasunanan dan Mangkunegaran ditetapkan dengan UU, maka Daerah tersebut untuk sementara waktu dipandang merupakan satu Karesidenan, dikepalai oleh seorang Residen yang memimpin segenap pegawai Pamong Praja dan Polisi serta memegang segala kekuasaan sebagai seorang Residen di Jawa dan Madura luar Daerah Surakarta dan Yogyakarta." Di samping itu, Penetapan Pemerintah tersebut juga menetapkan pembentukan daerah baru di dalam Karesidenan Surakarta dengan nama Kota Surakarta. Belakangan lahir UU No. 16 Tahun 1947 yang membentuk Haminte Kota Surakarta. 
dengan Residen Iskak Tjokroadisuryo dan wakilnya Soediro. Pada tanggal 9 November 1946 Iskak dan Soediro diculik oleh gerombolan politik tertentu, tetapi pemerintahan tetap berjalan di bawah Badan Eksekutif yang para anggotanya berasal dari wakil partai-partai politik. ${ }^{29}$

Karena kekacauan politik di Surakarta, Pemerintah Pusat turun tangan langsung untuk mengatasinya. Pada 6 Desember 1946, Gubernur Soetardjo Kartohadikosoemo mendapat tugas merangkap sebagai Residen Surakarta. Dalam suatu sidang DPR Surakarta 27 Februari 1947, Soetardjo mengajukan saran agar Kasunanan dan Mangkunegaran diberi Pemerintahan Otonom, tetapi sidang menolak. Apa yang ditentukan Soetardjo tentunya sejalan dengan keinginan Pemerintahan Pusat, tetapi elite politik di Surakarta menghendaki dipertahankannya Pemerintahan Karesidenan.

Berdasarkan UU No. 16 Tahun 1947, terjadilah proses pembentukan daerah Surakarta dalam bentuk Haminte (=Balaikota). Menurut UU ini, Haminte di Surakarta bersifat istimewa, karena dapat berhubungan langsung dengan Kementerian Dalam Negeri. Sebagai Walikota diangkat Sjamsurijal dan Soediro diangkat sebagai Residen. Badan Eksekutif Pemerintahan Balaikota adalah Dewan Pemerintahan Kota. Kota Surakarta menjadi pusat pemerintahan Karesidenan Surakarta. ${ }^{30}$

Pada 20 Desember 1948, tentara Belanda memasuki Kota Surakarta. Selama pendudukan itu Belanda telah membentuk "Pemerintahan Swapraja". Karena itu telah terjadi dualisme pemerintahan, yaitu Pemerintahan Balaikota di satu pihak, dan Pemerintahan Swapraja di lain pihak, yang menimbulkan pro dan kontra. Karena situasi yang memburuk Pemerintah RI, Daerah Surakarta berada dan dikendalikan dari luar kota.

Tetapi pada pertengahan Pebruari 1949 tersusun Pemerintahan Pamong Praja dalam kota yang para anggotanya sebagian besar terdiri dari para pelajar. Pemerintahan ini di bawah perlindungan Tentara Pelajar Rayon Kota, yang dikomandani oleh Achmadi. Munculnya "Pemerintahan Swapraja" yang dibuat oleh Belanda tersebut, telah memperkuat gerakan anti Swapraja, dan pada gilirannya juga memperkuat anti Daerah Istimewa Surakarta.

Setelah Belanda meninggalkan Surakarta pada akhir tahun 1949, Pemerintah RI melakukan berbagai penataan pemerintahan, termasuk pengembalian keberadaan Karesidenan Surakarta. Melalui Surat Keputusan Menteri Dalam Negeri No. F.X.3/

\footnotetext{
${ }^{29}$ Wirabumi, Op. Cit., hlm. 140.

${ }^{30}$ Ibid.
} 
1/13/1950 tertanggal 3 Maret 1950, pemerintahan Kasunanan dan Mangkunegaran dibekukan, dan hanya terbatas pada pemerintahan di dalam keraton saja. Dengan terbitnya Surat Keputusan Menteri Dalam Negeri tersebut, telah memantapkan keberadaan Karesidenan Surakarta, yang meliputi wilayah Kota Surakarta, Kabupaten Sukoharjo, Boyolali, Wonogiri, Klaten, Karanganyar, dan Sragen ${ }^{31}$ Sejak saat itu pengaturan tentang Daerah Istimewa Surakarta tidak pernah lagi dimunculkan di berbagai peraturan perundang-undangan, seolah-olah keistimewaan Surakarta sudah hilang eksistensinya.

Setelah lahirnya Penetapan Pemerintah No. 16/SD Tahun 1946 tertanggal 15 Juli 1946, maka sebelum bentuk/susunan pemerintahan daerah Kasunanan dan Mangkunegaran ditetapkan dengan Undang-undang, daerah tersebut dijadikan Karesidenan yang berada langsung di bawah pemerintah Republik Indonesia. Apalagi setelah lahirnya UU No. 22 Tahun 1948 dibentuk Provinsi Jawa Tengah dangan UU No. 10 Tahun 1950, daerah Karesidenan Surakarta tidak dibentuk sebagai Daerah Istimewa Surakarta melainkan menjadi bagian dari Provinsi Jawa Tengah. Dengan demikian, maka proses penghapusan Kasunanan dan daerah Mangkunegaran yang terjadi dari bawah, sementara waktu diperkuat dengan Penetapan Pemerintah No. 16/SD Tahun 1946 tanggal 15 Juli 1946, pada akhirnya dilegalisasi dengan UU No. 10 Tahun $1950 .^{32}$

\section{Upaya "Pengakuan" Kembali Daerah Istimewa Surakarta?}

Apabila dilakukan pencermatan ulang terhadap ketentuan Pasal 18B ayat (1) UUD 1945 (hasil perubahan), maka terdapat lima hal pokok, yaitu: bahwa (i) “negara mengakui", (ii) "negara menghormati", (iii) yang diakui dan dihormati itu adalah satuan-satuan pemerintahan daerah, (iv) satuan-satuan pemerintahan daerah dimaksud "bersifat khusus" atau "istimewa", dan bahwa (v) satuan-satuan

${ }^{31}$ Ibid., hlm. 141. Menurut Selo Soemardjan, di Surakarta baik Susuhunan maupun Mangkunegara melakukan segala cara untuk mempertahankan kerajaan dan rakyatnya agar tetap berada di bawah kekuasaan tradisional. Akan tetapi, kekuatan-kekuatan revolusioner di dalam masyarakat menjauhkannya dari kedua penguasa itu. Pemerintah kabupaten baru yang didirikan oleh KNID-KNID setempat mengeluarkan pernyataan menolak kekuasaan Susuhunan maupun Mangkunegara. Mereka memisahkan diri dari Kerajaan Surakarta dan Mangkunegara. Selain itu, mereka meminta agar diperintah langsung oleh pemerintah pusat Republik Indonesia. Pemerintah pusat membenarkan pernyataan pemerintah kabupaten. Mereka menyadari sikap Susuhunan dan Pangeran Mangkunegara yang tidak bisa diterima dan bertentangan dengan arus revolusi. Kekuasaan politik kedua penguasa itu dihapuskan sehingga Kerajaan Surakarta dan Mangkunegaran secara administratif dimasukkan ke dalam Propinsi Jawa Tengah. Selo Soemardjan, Perubahan..., Op. Cit., hlm. 95-96.

${ }^{32}$ Soedarisman Poerwokoesoemo, Daerah Istimewa..., Op. Cit., hlm. 259-260. 
pemerintahan daerah yang bersifat khusus atau istimewa tersebut diatur dengan undang-undang.

Tentang apa yang dimaksud dengan "negara mengakui", "negara menghormati", dan "bersifat khusus" apakah pengakuan tersebut harus bersifat retrospektif, artinya objek yang diakui (daerah) tersebut harus sudah ada terlebih dahulu dari pernyataan pengakuan, atau dapat juga bersifat proaktif dan forward looking, dimana objek yang diakui baru timbul setelah adanya pernyataan pengakuan. ${ }^{33}$

Ketentuan Pasal 18B ayat (1) UUD 1945 diadopsi dalam rumusan UUD Negara Republik Indonesia 1945 pada perubahan kedua 2000. Artinya, pernyataan pengakuan dalam Pasal 18B ayat (1) itu baru ada pada tanggal 18 Agustus 2000. Karena itu timbul persoalan, terutama dalam pemberian status khusus bagi suatu daerah, apakah satuan pemerintahan daerah yang dimaksudkan yang harus diakui dan dihormati oleh negara itu hanya satuan-satuan pemerintahan sebelum tanggal 18 Agustus 2000 saja, atau dapat pula bentuk-bentuk pemerintahan daerah yang baru. Terhadap permasalahan ini tentu dapat pula berkembang dua pendapat yang berbeda satu sama lain. Ada yang berpendapat bahwa yang diakui dan dihormati hanya satuan pemerintahan daerah yang bersifat khusus atau istimewa yang sudah ada sebelumnya, tetapi ada pula yang berpendapat bahwa satuan-satuan pemerintahan daerah yang baru mendapatkan status istimewa atau status khusus pun termasuk yang harus diakui dan dihormati. Permasalahan berikutnya adalah ketika unit pemerintahan daerah dimaksud akan diberi status sebagai daerah khusus atau istimewa, apakah Pasal 18B ayat (1) UUD 1945 dapat dijadikan dasar konstitusional dalam pemberian status tersebut? ${ }^{34}$ Misalnya, sebagai contoh pembentukan Provinsi Papua (dulunya Daerah Provinsi Irian Barat) sejak awal pembentukannya diberi status sebagai daerah otonom oleh UU No. 12 Tahun 1969 dan tidak berstatus sebagai daerah khusus atau pun istimewa. Pemberian status otonomi khusus pada Provinsi Papua lebih didasarkan kepada pertimbanganpertimbangan sosio-politik dan bukan karena adanya fakta kesejarahan (sejarah integrasi).

Demikian pula pemberian status keistimewaan bagi Provinsi Aceh pun tidak sejak awal pembentukan Provinsi Aceh, tetapi pemberian status keistimewaannya

\footnotetext{
${ }^{33}$ Yohanis Anton Raharusun, Daerah Khusus Dalam Perspektif NKRI, Konstitusi Press, Jakarta, 2009, hlm. 233.

${ }^{34}$ Ibid., hlm. 233-234.
} 
ketika masa reformasi dan transisi demokrasi melalui UU No. 44 Tahun 1999 yang diundangkan pada tanggal 4 Oktober 1999, juga lebih didasarkan kepada pertimbangan-pertimbangan sosio-politik karena masyarakat Aceh terus bergolak. Dalam perjalanan sejarah Pemerintahan Aceh ternyata pemberian status keistimewaan pun dipandang belum cukup karena secara substantif penyelenggaraan keistimewaan di Provinsi Aceh sama saja dengan daerah lain di Indonesia.

Hampir dua tahun berjalannya keistimewaan di Provinsi Aceh, Pemerintah menambah status baru lagi kepada Provinsi Aceh dengan otonomi khusus melalui UU No. 18 Tahun 2001 yang diundangkan pada tanggal 9 Agustus 2001. Lima tahun berselang kemudian, tepatnya tanggal 1 Agustus 2006 kembali lagi Pemerintah merubah status Provinsi Daerah Istimewa Aceh Sebagai Provinsi Nanggroe Aceh Darussalam menjadi Pemerintahan Aceh melalui UU No. 11 Tahun 2006. Di samping itu, melalui UU No. 11 Tahun 2006 tersebut Pemerintah mencabut status otonomi khusus bagi Provinsi Daerah Istimewa Aceh Sebagai Provinsi Nanggroe Aceh Darussalam dan sekaligus menyatakan tidak berlakunya UU No. 18 Tahun 2001. Dari peristiwa pergantian status Provinsi Aceh sebagai Daerah Istimewa yang kemudian ditambah lagi dengan status Otonomi Khusus dan kemudian diganti lagi bahkan dicabut status otonomi khususnya melalui berbagai undang-undang, menggambarkan secara jelas bahwa parameter pemberian status keistimewaan maupun status kekhususan bagi suatu daerah lebih didasarkan pada pertimbangan politis, tidak ada parameter yang jelas yang dapat dijadikan acuan bagi masyarakat untuk menentukan status bagi suatu daerah. Semuanya seolah sangat bergantung pada kepentingan Pemerintah Pusat dan daya tekan politis masyarakat di daerah yang bersangkutan. Adakalanya posisi Pemerintah Pusat sangat dominan menentukan status suatu daerah (status keistimewaan DIY), tetapi adakalanya Pemerintah Pusat berada di bawah tekanan politik masyarakat daerah tertentu (Provinsi Aceh dan Provinsi Papua). Seharusnya Pemerintah menentukan secara tegas dan jelas parameter pemberian status keistimewaan ataupun kekhususan bagi suatu daerah, sehingga eksistensi Pasal 18B ayat (1) UUD 1945 menjadi lebih bermakna dan mudah untuk dipahami, bukan sebaliknya sekedar menjadi 'pajangan' atau 'aksesoris' belaka.

Bagaimana kalau ada keinginan sekelompok masyarakat (tertentu) yang meminta agar status keistimewaan Surakarta dikembalikan? Upaya apa saja yang 
dapat dilakukan untuk mengembalikan status Surakarta sebagai Daerah Istimewa? Apakah keluarga kerajaan atau kerabat/keturunan Paku Buwono dapat melakukan “gugatan dan tuntutan" untuk mengembalikan status Surakarta sebagai daerah Istimewa ke Mahkamah Konstitusi melalui pengujian UU No. 10 Tahun 1950?

Jika ada pihak (masyarakat) yang menginginkan pengembalian status Surakarta sebagai Daerah Istimewa, pertanyaan yang muncul, (1) siapa yang menginginkan pengembalian status Surakarta dan kepada siapa status daerah istimewa tersebut akan dikembalikan? (2) wilayah yang mana yang akan diistimewakan? (3) dimana letak keistimewaannya? (4) apakah masyarakat Surakarta juga menginginkan pengembalian status Surakarta sebagai Daerah Istimewa? (5) apakah keluarga kerajaan/kadipaten Mangkunegaran juga menghendaki pengembalian status Surakarta sebagai daerah istimewa? Berbagai pertanyaan tersebut layak dikemukakan karena tuntutan pengembalian status Surakarta sebagai Daerah Istimewa bukanlah persoalan yang sederhana. Apalagi, secara historis telah diketahui bahwa dua kerajaan yang ada di Surakarta tersebut tidak pernah bisa menyatu seperti menyatunya dua kerajaan di Yogyakarta, sehingga perlu diperjelas, siapa yang menginginkan pengembalian status Surakarta sebagai Daerah Istimewa tersebut, wilayahnya yang mana saja yang akan dijadikan Daerah Istimewa, letak keistimewaannya dalam hal apa saja.

Upaya apa yang dapat dilakukan untuk mengembalikan status Surakarta sebagai daerah istimewa? Hingga saat ini belum ada pengaturan perihal pengembalian status daerah, apalagi pengembalian status daerah istimewa. Yang ada adalah peningkatan status dari daerah administratif berubah menjadi daerah otonom, pemekaran daerah, dan penghapusan daerah. Dengan demikian, apabila ada masyarakat yang menginginkan pengembalian status Surakarta sebagai Daerah Istimewa bisa ditempuh upaya pemekaran daerah, yaitu pemekaran dari Provinsi Jawa Tengah. Dengan demikian, prosedur pemekaran daerah yang diatur dalam PP No. 78 Tahun 2007 tentang Tata Cara Pembentukan, Penghapusan, dan Penggabungan Daerah harus diikuti. Menurut ketentuan PP No. 78 Tahun 2007, aspirasi pemekaran daerah tersebut harus didukung oleh sedikitnya 5 (lima) daerah kabupaten/kota, mendapat persetujuan dari DPRD masing-masing daerah, mendapat persejuan dari DPRD Provinsi Jawa Tengah, DPRD Provinsi Jawa Tengah, dan mendapat persetujuan Menteri Dalam Negeri. Setelah mendapatkan persetujuan dari berbagai pihak tersebut, barulah Presiden mengajukannya kepada DPR. 
Usulan tersebut akan diterima atau tidak, status hukumnya apakah menjadi daerah istimewa atau tidak, sangat bergantung pada pertimbangan-pertimbangan politik Pemerintah dan DPR, serta urgensi pemekaran bagi kepentingan masyarakat di daerah Surakarta.

Bagaimana seandainya masyarakat mengajukan gugatan dan tuntutan ke Mahkamah Konstitusi melalui pengujian UU No. 10 Tahun 1950 tentang Pembentukan Propinsi Djawa Tengah? Mahkamah bukanlah lembaga yang kompeten untuk memberikan persetujuan atau pun penolakan terhadap permohonan pengembalian status suatu daerah, misalnya status Surakarta sebagai Daerah Istimewa. Mahkamah Konstitusi merupakan lembaga peradilan yang diberi kewenangan antara lain untuk melakukan pengujian undang-undang terhadap undang-undang dasar. Mahkamah Konstitusi hanya akan menguji konstitusionalitas suatu undang-undang, serta kerugian konstitusional yang dialami oleh Pemohon akibat dikeluarkannya undang-undang tersebut.

Melihat persoalan tuntutan untuk pengembalian status Surakarta sebagai daerah istimewa dalam perspektif Pasal 18B ayat (1) UUD 1945 tentu tidak dapat hanya dilihat dari aspek yuridis semata, aspek lain juga perlu dipertimbangkan, misalnya historis 'hilangnya' status keistimewaan Surakarta dan juga faktor politis yang melingkupinya. Kajian historis tentang Surakarta yang dahulu diakui sebagai daerah istimewa tetapi kemudian dileburkan menjadi bagian dari Provinsi Djawa Tengah sebagaimana diuraikan di atas, tidak terlepas dari persoalan sejarah yang mengiringi perjalanan dua kerajaan (Kasunanan dan Mangkunegaran) di Surakarta di awal-awal kemerdekaan.

Parameter pemberian status keistimewaan bagi suatu daerah yang dipergunakan oleh Pemerintah hingga saat ini lebih didasarkan pada pertimbangan politis, tidak ada parameter yang jelas yang dapat dijadikan acuan bagi masyarakat untuk menentukan status bagi suatu daerah. Semuanya seolah sangat bergantung pada kepentingan Pemerintah Pusat dan daya tekan politis masyarakat di daerah yang bersangkutan. Adakalanya posisi Pemerintah Pusat sangat dominan menentukan status suatu daerah, tetapi adakalanya Pemerintah Pusat berada di bawah tekanan politik masyarakat di daerah tertentu. Seharusnya Pemerintah menentukan secara tegas dan jelas parameter pemberian status keistimewaan ataupun kekhususan bagi suatu daerah, sehingga eksistensi Pasal 18B ayat (1) UUD 1945 menjadi lebih bermakna dan mudah untuk dipahami. 
Namun demikian, jika masyarakat menginginkan menempuh melalui jalur pengujian di Mahkamah Konstitusi, maka harus melibatkan banyak pihak untuk ikut mendukung keinginan tersebut. Permohonan akan lebih kuat kalau semua pihak, misalnya Kraton Surakarta, Kadipaten Mangkunegaran, masyarakat di Kota Solo, dan daerah-daerah bekas Karesidenan Surakarta juga dilibatkan, sebagaimana upaya yang dilakukan di Yogyakarta, antara Kasultanan Yogyakarta dan Kadipaten Pakualaman bersatu padu bersama-sama masyarakat menuntut kejelasan status keistimewaan DIY. Tetapi, jika hanya diajukan oleh kelompok tertentu, sementara masyarakat Surakarta dan pihak-pihak lain justru menolak pengembalian status sebagai daerah istimewa, tentu akan menjadi langkah yang sia-sia.

\section{Penutup}

Dari kajian atas tiga permasalahan yang diajukan dalam penelitian ini, dapat disimpulkan sebagai berikut. Pertama, dalam perspektif historis, dihapuskannya Daerah Istimewa Surakarta karena munculnya gejolak sosial di masyarakat berupa "gerakan anti swapraja”, yang menuntut agar status keistimewaan Surakarta dicabut. Kedua, keistimewaan Surakarta dapat atau tidak diakui kembali sangat bergantung dari political will Pemerintah Pusat, DPR, Pemerintah Daerah, DPRD, dan masyarakat Surakarta (dan bekas Karesidenan Surakarta). Ketiga, upaya yang dapat dilakukan untuk diakuinya kembali Surakarta sebagai Daerah Istimewa, yaitu melalui pemekaran daerah atau melalui pengujian UU No. 10 Tahun 1950 ke Mahkamah Konstitusi.

Dalam melihat suatu persoalan tuntutan daerah untuk diberikan status sebagai daerah istimewa tidak dapat jika hanya dilihat dari aspek yuridis semata, tentu aspek lain juga perlu dipertimbangkan, misalnya historis 'hilangnya' status keistimewaan Surakarta dan juga faktor politis yang melingkupinya.

\section{Daftar Pustaka}

Anton Raharusun, Yohanis, Daerah Khusus dalam Perspektif NKRI, Konstitusi Press, Jakarta, 2009.

Atmakusumah (Penyunting), Tahta Untuk Rakyat, Gramedia, Jakarta, 1982.

Endi Jaweng, Robert, "Kritik terhadap Desentralisasi Asimetris di Indonesia”, Jurnal Analisis CSIS, Vol. 40, No. 2, Juni 2011. 
Gunawan, Jamil, dkk., (Editor), Desentralisasi,Globalisasi, dan Demokrasi Lokal, LP3ES, Jakarta, 2005.

Huda, Ni'matul, DIY dalam Perdebatan Konstitusi dan Peraturan Perundang-undangan di Indonesia, Nusa Media, Bandung, 2013.

Ibrahim, Johnny, Teori \& Metodologi Penelitian Hukum Normatif, Bayumedia, Malang, Cet. Kedua, 2006.

J. Suwarno, P., Hamengku Buwono IX dan Sistem Birokrasi Pemerintahan Yogyakarta 19421974: Sebuah Tinjauan Historis, Kanisius, Yogyakarta, 1994.

Lay, Cornelis, "Desentralisasi Asimetris Bagi Indonesia", makalah yang dipresentasikan dalam Seminar Nasional "Menata Ulang Desentralisasi dari Perspektif Daerah", yang diselenggarakan oleh Program Pascasarjana Program Studi Ilmu Politik Fisipol UGM kerjasama dengan USAID dan DRSP, Yogyakarta, 25 Januari 2010.

Liang Gie, The, Kumpulan Pembahasan terhadap Undang-Undang Tentang Pokok-pokok Pemerintahan Daerah Indonesia, Edisi Kedua, Cetakan Kedua, Supersukses, Yogyakarta, 1982.

, Pertumbuhan Pemerintahan Daerah di Negara Republik Indonesia, Liberty, Yogyakarta, 1993.

Poerwokoesoemo, Soedarisman, Daerah Istimewa Yogyakarta, Gadjahmada University Press, Yogyakarta, 1984.

S. Wirabumi, Edy, Pemberdayaan Hukum Otonomi Daerah dan Potensi Wilayah: Studi Tentang Kemungkinan Terbentuknya Provinsi Surakarta, Disertasi, Program Doktor Ilmu Hukum, Pascasarjana Universitas Diponegoro, Semarang, 2007.

Samroni, Imam, dkk.,(Penulis), Daerah Istimewa SURAKARTA, Wacana Pembentukan Provinsi Daerah Istimewa Surakarta Ditinjau dari Perspektif Historis, Sosiologis, Filosofis, \& Yuridis, Pura Pustaka, Yogyakarta, 2010.

Soemardjan, Selo, Perubahan Sosial di Yogyakarta, Gadjah Mada University Press, Yogyakarta, cet.ketiga, 1991.

Soemitro, Rochmat, Peraturan Perundang-undangan tentang Pemerintahan Daerah dari Tahun 1945 s/d 1983 dengan Komentar, Eresco - Tarate, Jakarta - Bandung, 1983.

Sujamto, Daerah Istimewa dalam Negara Kesatuan RI, Bina Aksara, Jakarta, 1988.

Indonesia, Undang-Undang Dasar Negara Republik Indonesia Tahun 1945.

Indonesia, Undang-Undang Nomor 1 Tahun 1945 tentang Peraturan Mengenai Kedudukan Komite Nasional Indonesia Daerah.

Indonesia, Undang-Undang No. 22 Tahun 1948 tentang Pemerintahan Daerah

Indonesia, Undang-Undang No. 10 Tahun 1950 tentang Pembentukan Propinsi Djawa Tengah.

Indonesia, Undang-Undang No. 11 Tahun 2006 tentang Provinsi Daerah Istimewa Aceh Sebagai Provinsi Nanggroe Aceh Darussalam 
Indonesia, Undang-Undang No. 13 Tahun 2012 tentang Keistimewaan Daerah Istimewa Yogyakarta.

Penetapan Pemerintah No. 16/SD Tahun 1946. 